\title{
PENGARUH KOMUNIKASI INTERPERSONAL DARI MUTU PELAYANAN INFORMASI TERHADAP KEPERCAYAAN PUBLIK DI KECAMATAN CARINGIN KABUPATEN BOGOR
}

\author{
THE INFLUENCE OF INTERPERSONAL COMMUNICATION FROM THE INFORMATION \\ SERVICE QUALITY TOWARDS TH PUBLIC TRUST IN CARINGIN SUB-DISTRICT DISTRICT OF \\ BOGOR
}

\author{
S Rahayu' ${ }^{1 a}$, IA Ratnamulyani², AA Kusumadinata ${ }^{3}$ \\ ${ }^{1}$ Alumni Ps. Ilmu Komunikasi, Fakultas Ilmu Sosial dan Ilmu Politik, Universitas Djuanda Bogor, ${ }^{2}$ Dosen \\ Pembimbing I Program Studi Komunikasi, Fakultas Ilmu Sosial dan Ilmu Politik, ${ }^{3}$ Dosen Pembimbing II \\ Program Studi Komunikasi Universitas Djuanda Bogor, Jl. Tol Ciawi No.1 Kotak Pos 35 Bogor 16720 \\ a Korespondensi: S Rahayu, Email: Srahayu377@yahoo.com
}

(Diterima: 08-02-2016; Ditelaah: 20-02-2016; Disetujui: 24-02-2016)

\begin{abstract}
This Study focused on the relationship of interpersonal communication from the information service quality towards the public trust. This study aims to find out interpersonal communication of srvic officers, to find out the public trust, and also to know the influnc of intrpersonal communication towards the public trust in Caringin, Bogor. The technique usd in accidental. The data from the questionnaire result then transferred into th analysis tabulation manually and next interpreted. Spearman's Rank on SPSS 18 is usdto calculate the influence. Th result using the analysis tabulation manually shows that $X$ variable (interpersonal communication) is at estimated figure of 4.0 which is categorised as good, where as $Y$ variable (the trust of pople) reaches 4.1 for the estimated figure and is also categorized as good. For the calculation of the influence, the coefficient correlation number $(r)$ is 0.486 categorised in the medium level.The conclusionis the correlation between the two variables has a tangible influence with significance of $\alpha 1 \%$ and shows a positive relation.
\end{abstract}

Key Words ; Interpersonal Communication, Public Trust, Information Srvice

\begin{abstract}
ABSTRAK
Penelitian ini memusatkan perhatian pada pengaruh komunikasi interpersonal dari mutu pelayanan informasi terhadap kepercayaan publik. Tujuan dari penelitian ini adalah untuk mengetahui komunikasi interpersonal petugas playanan, untuk mengetahui kepercayaan publik serta untuk mengetahui pengaruh komunikasi interpersonal terhadap kepercayaan publik di Kecamatan Caringin Kabupaten Bogor. Penelitian ini menggunakan metode penelitian kuantitatif dengan tknik sampel yang digunakan adalah aksidental. Data dari hasil kuesioner selanjutnya di masukkan ke dalam tabulasi analisis secara manual dan diinterpretasikan. Sedangkan untuk menghitung pengaruh menggunakan Rank Spearman pada SPSS 18. Berdasarkan hasil penelitian dengan menggunakan tabulasi analisis secara manual diketahui bahwa variabel X (komunikasi interpersonal) diperoleh angka penafsiran 4,0 yang berada pada kategori baik, dan pada variabel Y (kepercayaan publik) diperoleh angka penafsiran 4,1 yang berada pada kategori baik. Pada perhitungan pengaruh diperoleh nilai koefisien korelasi (r) sebesar 0,486 yang berada di level sedang, maka dapat disimpulkan bahwa korelasi diantara kedua variabel X (komunikasi interpersonal) dan variabel Y (kepercayaan publik) memiliki pengaruh yang nyata dengan signifikan $\alpha 1 \%$ serta menunjukan hubungan positif.
\end{abstract}

Kata Kunci : Komunikasi Interpersonal, Kepercayaan Publik, Pelayanan Informasi. 
S Rahayu, IA Ratnamulyani, AA Kusumadinata. 2016. Pengaruh Komunikasi Interpersonal dari Mutu Pelayanan Informasi Terhadap Kepercayaan Publik di Kecamatan Caringin Kabupaten Bogor. Jurnal Komunikatio 2(1):. Halaman 57-65. 


\section{PENDAHULUAN}

Kegiatan komunikasi antara petugas pelayanan dengan masyarakat sebagai penerima pelayanan dapat disimpulkan sebagai interaksi dalam komunikasi. Komunikasi yang kurang efektif antara pemberi pelayanan dengan masyarakat dapat menyebabkan pengertian yang berbeda terutama dalam memberikan informasi seperti persyaratan administrasi pembuatan Kartu Tanda Penduduk (KTP) dan Kartu Keluarga (KK) yang membuat masyarakat menjadi kecewa karena harus menunggu beberapa hari disebabkan formulir pembutan KTP dan KK ditunda pencetakannya karena tidak sesuai administrasi. Selain itu, kurangnya informasi mengenai tindak lanjut Surat Keterangan Pindah khusus antar Kota/Kabupaten dan antar provinsi yang pengurusannya sampai Dinas Kependudukan dan Catatan Sipil (DisdukCapil) Kota/Kabupaten. Berdasarkan data di Kecamatan Caringin, jumlah pelayanan KTP dan KK adalah :

Pelayan publik di kecamatan harus dapat melayani masyarakat dengan sebaik-baiknya. Masyarakat yang ingin mendapatkan pelayanan terdiri dari berbagai latar belakang dan kepentingan yang berbeda. Hal ini akan mudah terjadi kesalahpahaman apabila petugas layanan kurang menyesuaikan dengan masyarakat. Pelayanan yang diberikan oleh kecamatan meliputi banyak hal, akan tetapi masyarakat yang datang ke kecamatan lebih banyak mengurus KTP, KK, Surat Keterangan Pindah dan Surat Keterangan Keluarga Miskin (SKKM). Hal tersebut yang membuat petugas layanan harus memberikan informasi yang jelas agar masyarakat mengerti dan mendapatkan apa yang diinginkan.

\section{Pokok Masalah}

1. Bagaimana komunikasi interpersonal petugas pelayanan di Kecamatan Caringin Kabupaten Bogor?

2. Bagaimana kepercayaan publik di Kecamatan Caringin Kabupaten Bogor?

3. Bagaimana pengaruh komunikasi interpersonal terhadap kepercayaan publik di Kecamatan Caringin Kabupaten Bogor?

\section{Tujuan Penelitian}

Tujuan penelitian ini adalah : 1 . Untuk mengetahui komunikasi interpersonal petugas pelayanan di Kecamatan Caringin Kabupaten
Bogor. 2. Untuk mengetahui kepercayaan publik di Kecamatan Caringin Kabupaten Bogor. 3. Untuk mengetahui pengaruh komunikasi interpersonal terhadap kepercayaan publik di Kecamatan Caringin Kabupaten Bogor.

\section{Tinjauan Pustaka}

Menurut Effendy, (2003) komunikasi antarpribadi adalah proses pengiriman dan penerimaan pesan-pesan antara dua orang atau di antara sekelompok kecil orang-orang, dengan beberapa efek dan beberapa umpan balik seketika (the process of sending and receiving messages between two persons,or among a small group of persons, with some effect and some immediate feedback).

Komunikasi yang efektif adalah komunikasi yang menimbulkan efek tertentu sesuai dengan tujuan yang diharapkan oleh komunikator.

Komunikasi Interpersonal berlangsung antar dua individu, karenanya pemahaman komunikasi dan hubungan antar pribadi menempatkan pemahaman mengenai komunikasi dalam proses psikologis. Setiap individu dalam tindakan komunikasi memiliki pemahaman dan makna pribadi terhadap setiap hubungan dimana dia terlibat di dalamnya. Hal terpenting dari aspek psikologis dalam komunikasi adalah asumsi bahwa diri pribadi individu terletak dalam diri individu dan tidak mungkin diamati secara langsung. Artinya dalam komunikasi interpersonal pengamatan terhadap seseorang dilakukan melalui perilakunya dengan mendasarkan pada persespsi orang yang mengamati. Dengan demikian aspek psikologis mencakup pengamatan pada dua dimensi, yaitu internal dan eksternal. Namun kita mengetahui bahwa dimensi eksternal tidaklah selalu sama dengan dimensi internalnya.

Komunikasi menuntut adanya partisipasi dan kerja sama dari para pelaku yang terlibat kegiatan komunikasi akan berlangsung baik apabila pihak-pihak yang berkomunikasi (dua orang atau lebih) sama-sama ikut terlibat dan sama-sama mempunyai perhatian yang samaterhadap topik pesan yang disampaikan.

Menurut Fajar, (2009) mengemukakan bahwa kegiatan komunikasi pada prinsipnya adalah aktifitas pertukaran ide atau gagasan. Secara sederhana, kegiatan komunikasi dipahami sebagai kegiatan penyampaian dan penerimaan pesan atau ide dari satu pihak ke pihak lain, dengan tujuan untuk mencapai 
kesamaan pandangan atas ide pertukaran tersebut.

Kegagalan dalam berkomunikasi sering terjadi karena banyak hambatan-hambatan. Salah satu hambatan yang ditimbulkan dari unsur manusia yang terlibat didalamnya ialah karena persepsi yang berbeda. Dimana dalam persepsi ada kecenderungan menghambat informasi baru, terutama jika informasi ini bertentangan dengan apa yang diyakini. Persepsi pada hakekatnya adalah proses kognitif yang dialami oleh setiap orang didalam memakai informasi tentang lingkungannya, lewat penglihatan, pendengaran, penghayatan, perasaan dan penciuman.

Miftah Thoha, (2009) mengungkapkan bahwa komunikasi interpersonal dapat efektif dengan lima hal berikut yaitu:

a. Keterbukaan : paling sedikit terdapat dua aspek untuk menunjukan keterbukaan dalam komunikasi interpersonal yaitu aspek keinginan untuk terbuka bagi setiap orang yang berinteraksi dengan orang lain dan aspek lainnya ialah keinginan untuk menanggapi secara jujur semua informasi yang datang kepadanya.

b. Empati : dalam hal ini yaitu merasakan bagaimana yang dirasakan oleh orang lain, yakni mencoba merasakan dalam cara yang sama dalam mengerti perasaan orang lain.

c. Dukungan : dukungan dapat menentukan keberhasilan komunikasi interpersonal. Adakalanya dukungan dapat terucapkan ataupun tidak, dukungan yang tidak terucapkan biasanya berupa anggukan, kedipan mata, tepuk tangan, senyuman, dan lain-lain. Kita memperlihatkan sikap mendukung dengan bersikap (1) deskriptif, bukan evaluatif, (2) spontan, bukan strategic, dan (3) provisional, bukan sangat yakin.

d. Kepositifan : pada aspek ini sedikitnya terdapat tiga perbedaan atau unsur. Pertama, komunikasi interpersonal akan berhasil jika terdapat perhatian yang positif terhadap diri seseorang, kedua komukasi interpersonal dapat terpelihara dengan baik jika jika perasaan positif dapat dikomunikasikan kepada orang lain, ketiga perasaan positif dapat bermanfaat untuk mengefektifkan kerjasama dalam situasi umum.

e. Kesamaan : Jika dalam situasi yang sama komunikasi interpersonal biasanya akan berjalan efektif, namun bukan berarti orang yang tidak memiliki kesamaan tidak bisa berkomunikasi, akan tetapi jika memperhatikan kesamaan kepribadian maka kesamaan berarti kita menerima pihak lain.

Komunikasi antarpribadi sebenarnya merupakan suatu proses sosial dimana orangorang yang terlibat di dalamnya saling mempengaruhi. Proses saling mempengaruhi ini merupakan suatu proses bersifat psikologis dan karenanya juga merupakan permulaan dari ikatan psikologis antarmanusia yang memiliki suatu pribadi.

Pelayanan Publik (Public Service) adalah salah satu produk dari organisasi pemerintahan, begitupun yang ada di kecamatan Caringin.Pelayanan tersebut diberikan untuk memenuhi hak masyarakat, baik itu merupakan layanan sipil maupun layanan publik. Artinya kegiatan pelayanan pada dasarnya menyangkut pemenuhan suatu hak.Ia melekat pada setiap orang, baik secara pribadi maupun berkelompok (organisasi), dan dilakukan secara universal. Hal ini seperti yang diungkapkan oleh Moenir (1998) bahwa "hak atas pelayanan itu sifatnya sudah universal, berlaku terhadap siapa saja yang berkepentingan atas hak itu, dan oleh organisasi apa pun juga yang tugasnya menyelenggarakan pelayanan."

Menurut Kotler dalam Laksana, (2008) pelayanan adalah setiap tindakan atau kegiatan yang dapat ditawarkan oleh suatu pihak kepada pihak lain, yang pada dasarnya tidak berwujud dan tidak mengakibatkan kepemilikan apapun.

Sedangkan Gronroos dalam Tjiptono, (2005) menyatakan bahwa pelayanan merupakan proses yang terdiri atas serangkaian aktivitas intangible yang biasa (namun tidak harus selalu) terjadi pada interaksi antara pelanggan dan karyawan, jasa dan sumber daya, fisik atau barang, dan sistem penyedia jasa, yang disediakan sebagai solusi atas masalah pelanggan.

Kepercayaan (trust) merupakan kesediaan (willingness) individu untuk mengantungkan dirinya pada pihak lain yang terlibat pertukaran karena individu mempunyai keyakinan (confidence) terhadap pihak lain menurut Moorman, (1993) dalam Darsono, (2008). Kepercayaan lebih mudah untuk tumbuh di antara orangorang yang memiliki kapentingan dan tujuan yang sama, sehingga lebih mudah untuk mengubah kepercayaan 
individu daripada mengubah kepercayaan suatu kelompok. Kepercayaan merupakan bagian dari sikap. Sikap terdiri dari aspek kognitif, afektif dan konasi. Kepercayaan adalah aspek yang dibentuk dalam kognitif menurut Azwar, (2007). Kepercayaan merupakan salah satu hal yang memiliki peranan penting dalam menentukan sikap. Kepercayaan terhadap pelayananpublik akan menentukan sikap masyarakat dalam menentukan kepuasan dalam pelayanan.Untuk menentukantrustlevel tidak dapat hanya menanyakan apakah individu percaya atau tidak percaya kepada pihak lain. Kepercayaan merupakan manifestasi dari berbagai persepsi yang berkembang dalam pemikiran manusia.

Menurut Robbins, (2002) dimensi trust terdiri dari lima bagian, yaitu :

a. Integrity, yakni individu yakin bahwa pihak lain akan berlaku jujur dan berlaku sebenarnya.

b. Competence, yakni memiliki pengetahuan dan keahlian teknik interpersonal.

c. Consistency, yakni reliabilitas, prediktibilitas dan keputusan tepat dari individu dalam menghadapi situasi tertentu.

d. Loyalty, yakni kemauan untuk melindungi nama baik orang lain.

e. Opennes, yakni seseorang yang percaya memiliki kemauan untuk berbagi ide, pemikiran, dan perasaan kepada pihak lain.

\section{METODOLOGI PENELITIAN}

Penelitian ini menggunakan metode penelitian Kuantitatif. Menurut Sugiyono, (2012) metode penelitian kuantitatif dapat diartikan sebagai metode penelitian yang berlandaskan pada filsafat positivisme, digunakan untuk meneliti pada populasi atau sampel tertentu. .Penelitian dilakukan di Kecamatan Caringin, di Jalan Raya Mayjen HE. Sukma No.1 KM. 17 Caringin Kabupaten Bogor. Penelitian ini dimulai pada bulan Maret sampai dengan bulan Mei Tahun 2015.

Pengumpulan data diambil dari perolehan data primer dan data sekunder yang berhubungan dengan kajian yang akan diteliti. Perolehan data primer melalui rancangan survei dengan menggunakan penyebaran kuesioner dan wawancara. Sedangkan data sekunder melalui hasil observasi untuk meyakinkan bahwa penelitian dapat dilakukan.
Wawancara, yaitu suatu teknik pengumpulan data dengan mendapatkan informasi dengan cara bertanya langsung kepada responden.

Angket/Kuesioner, yaitu salah satu teknik yang digunakan melalui cara mengajukan beberapa pertanyaan kepada responden untuk memperoleh informasi yang relevan dengan permasalahan yang diteliti. Kuesioner diberikan dalam bentuk pertanyaan tertutup karena jawabannya telah ditentukan peneliti terlebih dahulu sehingga responden hanya memilih alternatif sesuai dengan keadaan sebenarnya.

\section{HASIL DAN PEMBAHASAN}

Hasil uji validitas $\mathrm{X}$

Syarat yang digunakan adalah pearson correlation lebih besar dari $r$ tabel 0,298 jika kurang dari 0,298 maka point instrumen di anggap gugur atau tidak valid.

Tabel 1. Tabel Keterangan Uji Validitas Variabel X

\begin{tabular}{|c|c|c|c|}
\hline $\begin{array}{c}\text { No } \\
\text { Soal }\end{array}$ & $\begin{array}{c}\mathrm{R} \\
\text { Hitung }\end{array}$ & R tabel & Keterangan \\
\hline 1 & 0,732 & $>0,298$ & Valid \\
\hline 2 & 0,732 & $>0,298$ & Valid \\
\hline 3 & 0,615 & $>0,298$ & Valid \\
\hline 4 & 0,816 & $>0,298$ & Valid \\
\hline 5 & 0,432 & $>0,298$ & Valid \\
\hline 6 & 0,732 & $>0,298$ & Valid \\
\hline 7 & 0,402 & $>0,298$ & Valid \\
\hline 8 & 0,816 & $>0,298$ & Valid \\
\hline 9 & 0,482 & $>0,298$ & Valid \\
\hline
\end{tabular}

Hasil uji reliabilitas variabel X

Apabila didapatkan nilai Croanbach's Alpha kurang dari 0,600 berarti buruk, sekitar 0,700 diterima dan lebih dari atau sama dengan 0,800 adalah baik. Pada data di atas didapat cronbach's alpha 0,884 yang berarti baik, sehingga variabel X (komunikasi interpersonal) bernilai baik.

Hasil uji validitas variabel Y

Syarat yang digunakan adalah pearson correletion lebih besar dari $r$ tabel 0,297 jika kurang dari 0,297 maka point instrumen di anggap gugur atau tidak valid. 
Tabel 2. Keterangan Uji Validitas Variabel Y

\begin{tabular}{|c|l|l|l|}
\hline & $\begin{array}{l}\text { R } \\
\text { Hitung }\end{array}$ & R tabel & Keterangan \\
\hline 1 & 0,831 & $>0,298$ & Valid \\
\hline 2 & 0,630 & $>0,298$ & Valid \\
\hline 3 & 0,989 & $>0,298$ & Valid \\
\hline 4 & 0,989 & $>0,298$ & Valid \\
\hline 5 & 0,831 & $>0,298$ & Valid \\
\hline 6 & 0,989 & $>0,298$ & Valid \\
\hline 7 & 0,591 & $>0,298$ & Valid \\
\hline 8 & 0,989 & $>0,298$ & Valid \\
\hline
\end{tabular}

Hasil uji reliabilitas variabel Y

Apabila didapatkan nilai Croanbach's Alpha kurang dari 0,600 berarti buruk, sekitar 0,700 diterima dan lebih dari atau sama dengan 0,800 adalah baik. Pada data di atas didapat cronbach's alpha 0,958 yang berarti baik, sehingga variabel $\mathrm{Y}$ (kepercayaan publik) bernilai baik.

Uji hipotesis untuk mengetahui hubungan antara komunikasi interpersonal dengan kepercayaan publik secara menyeluruh berdasarkan uji korelasi product moment, yang dapat dilihat dari tabel dibawah ini :

Berdasarkan hasil SPSS antara komunikasi interpersonal dengan Kepercayaan publik didapat koefisien sebesar $0,486^{* *}$. Hal ini menunjukkan bahwa komunikasi interpersonal pada variabel $\mathrm{X}$ memiliki pengaruh yang nyata dengan signifikan pada $\alpha$ 1 $\%$ terhadap kepercayaan publik pada variabel $Y$, ini dikarenakan komunikasi interpersonal sangat diperlukan dalam pelayanan informasi sehingga dapat menimbulkan kepercayaan publik.

\section{Hubungan Antar Variabel}

Analisis hubungan antara komunikasi interpersonal dari mutu pelayanan informasi terhadap kepercayaan publik di Kecamatan Caringin Kabupaten Bogor, berdasarkan uji korelasi product moment dengan metode SPSS 18, diperoleh gambaran hubungan variabel komunikasi interpersonal dengan kepercayaan publik yang diuraikan dalam beberapa indikator, terlihat pada tabel berikut ini : 
Tabel 27

Pengaruh Variabel X (Komunikasi Interpersonal) dari Mutu Pelayanan Informasi Terhadap Variabel Y (Kepercayaan Publik) Di Kecamatan Caringin Kabupaten Bogor

\begin{tabular}{|l|l|c|}
\hline & \multicolumn{1}{|c|}{ Integritas } & Loyalitas \\
\hline Berinteraksi &, 226 &, 044 \\
\hline Informasi &, $407^{* *}$ &, 126 \\
\hline Empati &, $300^{*}$ &, 259 \\
\hline $\begin{array}{l}\text { Pelayanan cepat } \\
\text { dan tepat }\end{array}$ &, $408^{* *}$ & \\
\hline
\end{tabular}

Keterangan : ** Pengaruh signifikan/nyata

Berdasarkan tabel diatas, diketahui hubungan variabel Komunikasi Interpersonal Dalam Membangun Kepercayaan Publik yang diuraikan dalam beberapa indikator memilki nilai koefisien korelasi berkisar antara 0 sampai 1 atau 0 sampai -1. Semakin mendekati 1 atau -1 maka hubungan semakin erat.Jika mendekati 0 maka hubungan semakin lemah.

\section{Penafsiran Pengaruh Variabel komunikasi Interpersonal dengan} Variabel Kepercayaan Publik

Pada tabel 26 dijelaskan hubungan komunikasi interpersonal dengan kepercayaan publik yang dijelaskan dalam beberapa indikator, yaitu sebagai berikut :

1. Keterbukaan (komunikasi interpersonal) pada variabel $\mathrm{X}$ yaitu Informasi memiliki pengaruh yang sangat signifikan terhadap kepercayaan publik yakni integritas dengan angka penafsiran $0,407^{* * *}$. Hal ini dikarenakan informasi yang diberikan secara jelas oleh petugas pelayanan dapat diterima dengan baik oleh masyarakat sehingga menimbulkan kepercayaan publik.

2. Keterbukaan (komunikasi interpersonal) pada variabel $X$ yaitu empati memiliki pengaruh yang cukup signifikan terhadap kepercayaan publik yakni integritas dengan angka penafsiran $0,300^{*}$.. Hal ini dikarenakan empati dapat membuat komunikasi interpersonal berjalan lancar sehingga dapat menimbulkan kepercayaan publik.

3. Ketanggapan

(komunikasi interpersonal) pada variabel $\mathrm{X}$ yaitu pelayanan cepat dan tepat memiliki pengaruh yang sangat signifikan terhadap kepercayaan publik yakni integritas dengan angka penafsiran $0,408^{* * *}$. Hal ini dikarenakan pelayanan yang cepat dan tepat dapat diterima dengan baik oleh masyarakat sehingga menimbulkan kepercayaan publik. 


\section{KESIMPULAN DAN SARAN}

\section{Kesimpulan}

Berdasarkan uraian hasil penelitian pada bab-bab sebelumnya, maka dapat disimpulkan sebagai berikut:

Komunikasi interpersonal yang dilakukan petugas pelayanan dapat diterima oleh masyarakat dikarenakan petugas dapat bersikap terbuka dalam berinteraksi dan memberikan informasi yang jelas. Hal ini yang dapat menunjang kelancaran kegiatan pelayanan publik terhadap masyarakat sebagai penerima pelayanan.

Kepercayaan publik terhadap pelayanan di Kecamatan Caringin terjadi karena adanya integritas yang tinggi dari masyarakat terhadap petugas dan instansi yang melaksanakan pelayanan publik serta adanya loyalitas yang tinggi terhadap petugas pelayanan dari masyarakat.

Pengaruh komunikasi interpersonal terhadap kepercayaan public besar karena semakin tinggi tingkat komunikasi interpersonal seorang petugas dalam pelayanan publik, maka akan semakin besar kepercayaan publik terhadap petugas dan instansi yang melaksanakan pelayanan publik.

\section{Saran}

Berdasarkan dari hasil penelitian terdapat beberapa saran yang dapat penulis kemukakan yaitu :

Petugas pelayanan diharapkan dapat memberikan pelayanan yang baik dengan menggunakan komunikasi interpersonal dengan tetap menyadari pentingnya interaksi langsung tatap muka dengan masyarakat sebagai penerima pelayanan sehingga diharapkan dapat menghasilkan kepercayaan publik.

Diperlukan intropeksi diri pada petugas pelayanan sebagai ukuran dalam melaksanakan pelayanan publik sehingga tidak mengalami kemunduran dalam melayani masyarakat yang dapat menyebabkan ketidakpercayaan publik. 


\section{DAFTAR PUSTAKA}

Arikunto. 2007. Manajemen Penelitian, Jakarta : Rineka Cipta.

Azwar, S. 2007. Realibilitas dan Validitas, Yogyakarta : Pustaka Pelajar.

Bungin, Burhan. 2008. Sosiologi Komunikasi, Jakarta : Prenada Media Group.

Darsono. 2008. Penganggaran Perusahaan, Jakarta : Mitra Wancana Media.

Priyatno, Dwi. 2008. Mandiri Belajar SPSS, Yogyakarta : MediaKom.

Effendy, Onong Uchjana. 1985. Ilmu Komunikasi, Teori dan Praktek, Bandung : CV. Remaja Karya.

2003. Ilmu,

Teori dan Filsafat Komunikasi, Bandung : Citra Aditya Bakti.

2007. IImu

Komunikasi Teori dan Praktek, Bandung : Remaja Rosda Karya.

Fajar, Marhaeni. 2009. Ilmu Komunikasi : Teori dan Praktik, Jakarta : Graha Ilmu.

Laksana, Fajar. 2008 Manajemen Pemasaran Pendekatan Praktis, Yogyakarta : Graha Ilmu.

Miftah, Thoha. 1995. Perilaku Organisasi Konsep Dasar dan Aplikasinya, Jakarta : Raja Grafindo Persada. 2009. Kepemimpinan Dalam Manajemen, Jakarta : Raja Grafindo Persada.

Moenir, HAS. 1998. Manajemen Pelayanan Publik, Jakarta : Bina Aksara. 2006. Manajemen Pelayanan

Umum di Indonesia, Jakarta : Bumi Aksara.

Nawawi, Hadari. 1995. Metode Penelitian Sosial, Yogyakarta : Gajah Mada University Press.

Parasuraman. 1990. Delivering Quality Service, New York : The Free Press.

Payne Adrian. 2000. The Essence of Service Marketing Pemasaran Jasa, Yogyakarta : ANDI.

Siregar, Bakri. 1981. Metode Riset Sosial Suatu Pengantar, Jakarta : Erlangga.

Singarimbun, Masri dan Sofian Effendi. 1995. Metode Penelitian Survai, Jakarta : LP3S.

Santoso. 2005. Metode Suatu Penelitian, Jakarta : Rineka Aksara.

Sugiyono. 2008. Statistika untuk Penelitian, Bandung : Alfa Beta.
2011. Statistik untuk Penelitian, Bandung : Alfabeta.

__ 2012. Pengantar Metode Penelitian Kuantitatif Kualitatif R\&D, Bandung : Alfabeta.

Robbins. 2002. Perilaku Organisasi, Jakarta : Prenhalindo.

Tjiptono, Fandy. 2005. Service, Quality \& Satisfaction, Yogyakarta : ANDI.

\section{Sumber Website}

http://administrasidanmanajemen.blogspot.co $\mathrm{m} / 2009 / 01 /$ prinsip-prinsip- pelayananprima) diakses pada 14 Juli 201420.00 Wib. 
